\title{
Intradural Extramedullary Spinal Metastasis of a Kidney Cancer: Case Report
}

\section{Metástase espinhal intradural extramedular de carcinoma renal: relato de caso}

\author{
Marina Piquet Sarmento ${ }^{1}$ Leandro José Haas ${ }^{2}$ Letícia Saori Tutida ${ }^{1}$ Natália Tozzi Marques ${ }^{1}$ \\ Thaize Regina Scramocin ${ }^{1}$ Omar Ahmad Omar ${ }^{1}$ Evelyn Della Giustina ${ }^{1}$ Felipe Trevisan Sartori ${ }^{1}$ \\ Liz Caroline Camilo ${ }^{1}$ Thaís Moura Borille ${ }^{1}$ Celso Itiberê Bernardes ${ }^{3}$ Vitor Hugo Boer ${ }^{3}$ Danielle Lara ${ }^{3}$ \\ Filipe Laurindo Cabral ${ }^{3}$ Luís Renato Mello ${ }^{3}$
}

${ }^{1}$ School of Medicine, Fundação Universidade Regional de Blumenau, Blumenau, SC, Brazil

${ }^{2}$ Department of Neurosurgery and Interventional Neuroradiology, Hospital Santa Isabel, Blumenau, SC, Brazil

${ }^{3}$ Department of Neurosurgery, Hospital Santa Isabel, Blumenau, SC, Brazil

Arq Bras Neurocir 2019;38:42-46.
Address for correspondence Marina Piquet Sarmento, MD, Faculdade de Medicina, Fundação Universidade Regional de Blumenau (FURB), Rua Júlio Kleine, 809, Bairro Fortaleza, Blumenau-SC, CEP 89057-050, Brazil (e-mail: marina.piquet94@gmail.com).

\section{Abstract \\ Keywords \\ - neoplasm metastasis \\ - kidney neoplasms \\ - intradural metastasis}

\section{Resumo}

Objective To report a case of intradural extramedullary metastasis originated from a kidney neoplasm. Metastases in this topography occur in a low frequency, especially considering that the primary tumor was located along the urinary system.

Case Report A male adult begins to present with pain in the lower limbs and develops flaccid paraparesis of the pelvic limbs, also attacking the control of the sphincter. The patient had a previous history of right nephrectomy due to a kidney neoplasm. After investigation with imaging exams, a metastatic lesion was found to be the source of the symptoms. The patient was surgically treated by the neurosurgery team of the hospital.

Conclusion Cases like this are not common, and considering the low incidence of these cases and the nonspecific symptoms, such as pain, we do not always come up with the hypothesis of a metastasis in this topography. The surgical treatment, although it is a palliative feature, has an important part in maintaining the performance and the quality of life of the patient.

Objetivo Relatar um caso de metástase intradural extramedular de um carcinoma renal. Metástases nesta topografia são de baixa ocorrência, ainda mais tratando-se de um tumor primário no sistema urinário.

Relato de caso Paciente adulto do sexo masculino que inicia quadro de dor nos membros inferiores, evoluindo com paraparesia crural, tem piora do quadro, acometendo a função esfincteriana. O paciente possuía um histórico prévio de nefrectomia por neoplasia maligna em sítio renal. Após investigação com exames complementares, received September 19, 2018 accepted January 8, 2019
DOI https://doi.org/ $10.1055 / \mathrm{s}-0039-1678588$ ISSN 0103-5355.
Copyright $\odot 2019$ by Thieme Revinter Publicações Ltda, Rio de Janeiro, Brazil
License terms

(c) (i) $\ominus$ () 


\section{Palavras-chave}

- metástase neoplásica

- neoplasias renais

- metástases intradurais foi detectada a lesão metastática responsável pelos sintomas. A mesma foi tratada cirurgicamente pela equipe de neurocirurgia do serviço.

Conclusão Casos como este não são comuns e nem sempre nos levam a aventar a hipótese de metástase nesta topografia, frente à baixa incidência e ao início de sintomas muitas vezes inespecíficos, como dor. O tratamento, apesar de paliativo, tem um papel importante na qualidade de sobrevida do paciente.

\section{Introduction}

Cancer is currently a highly prevalent disease, and a metastatic disease occurs as the clinical picture progresses. Systemic neoplasms with distant metastasis to the spine range from 30 to $40 \%{ }^{1,2}$ Considering the spine, intradural extramedullary metastases are rare and represent $\sim 1 \%$ of the cases. $^{3-5}$ The age group with higher prevalence of cases is between 40 and 60 years old. ${ }^{4}$ Metastatic dissemination is variable and related to the histological type of the primary tumor, as well as to its primary location. ${ }^{4,5}$

Schwannomas, meningiomas, and neurofibromas are the primary central nervous system (CNS) tumors that most frequently send metastatic implants to the intradural compartment, ${ }^{3,6}$ while the major systemic neoplasms that metastasize to the spine are breast, lung, and prostate tumors. ${ }^{4,7}$ As technology advances, such specific diagnoses are now possible and assist in the treatment. ${ }^{8}$ Primary renal cancer is one of the most uncommon amongst this narrow group of neoplasms, thus the relevance of the following reported case.

\section{Case Report}

A 62-year-old man reporting bilateral lower limb weakness for some time. The condition worsened 10 days before, when he became incapable of walking and presented with bowel and bladder dysfunction. The initial physical examination confirmed an asymmetric paraparesis, with the left side being more affected (muscle strength graded 2 on left leg and 3 on the right), as well as knee jerk hyporeflexia, and preserved sensitivity.

Previous medical history: diabetes mellitus, chronic arterial hypertension. Right nephrectomy 4 years before, due to a malignant kidney neoplasm.

Through the anamnesis and a physical examination, medullary compression was the hypothesis inferred. In order to advance the investigation, a lumbar spine magnetic resonance imaging (MRI) exam was requested. (-Figs. 1-5)

The MRI showed an intradural extramedullary heterogeneous expansive lesion located posterior to the L3 vertebral body and glancing to the L3-L4 right foramen, probably corresponding to a schwannoma. In association, intradural hemorrhagic content is observed, extending from the lesion to the sacral region.

An L3-L4 laminectomy was performed, a middle line opening on dural topography, microscopically, a gray soften mass could be visualized. Using standardized microsurgical techni- ques, the lesion was completely removed without adverse events. The metastasis was confirmed by histological analysis.

During the postoperative recovery, the patient presented melena, therefore the gastroenterology team was requested to evaluate him as well. An upper endoscopy was performed, revealing an elevated duodenal lesion located in the middle third, just above the major duodenal papilla. The lesion measured $\sim 15 \mathrm{~mm}$, was rounded and depressible, and showed erosion on its surface. The patient was discharged from the hospital on the $9^{\text {th }}$ day postsurgery, presenting

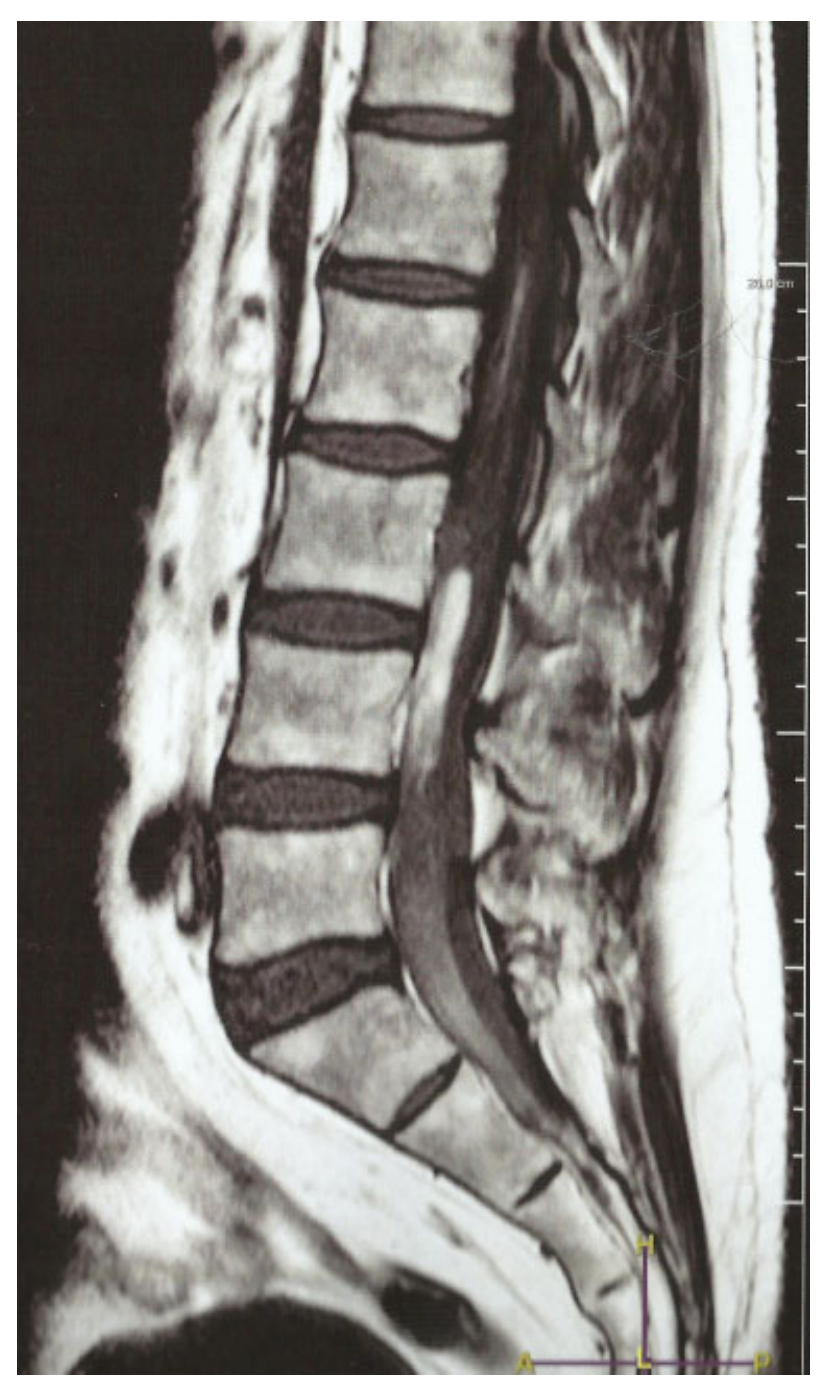

Fig. 1 Sagittal T1 lumbosacral magnetic resonance imaging showing an intradural extramedullary heterogeneous expansive lesion located posterior to the $\mathrm{L} 3$ vertebral body and glancing to the L3-L4 right foramen. 


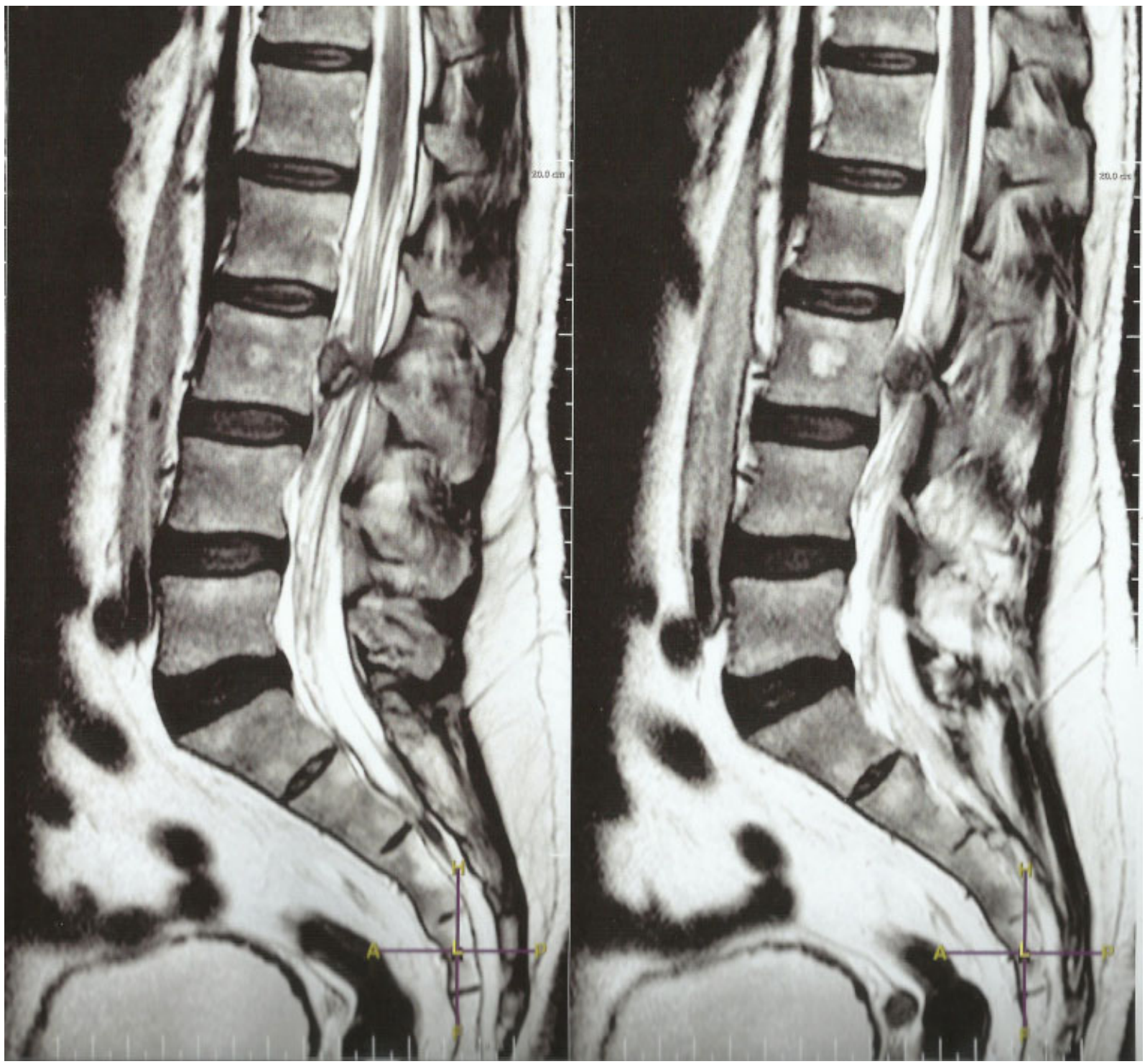

Fig. 2 Sagittal T2-weighted lumbosacral magnetic resonance imaging highlighting the intradural extramedullary heterogeneous expansive lesion located posterior to the L3 vertebral body and projecting to the L3-L4 right foramen.

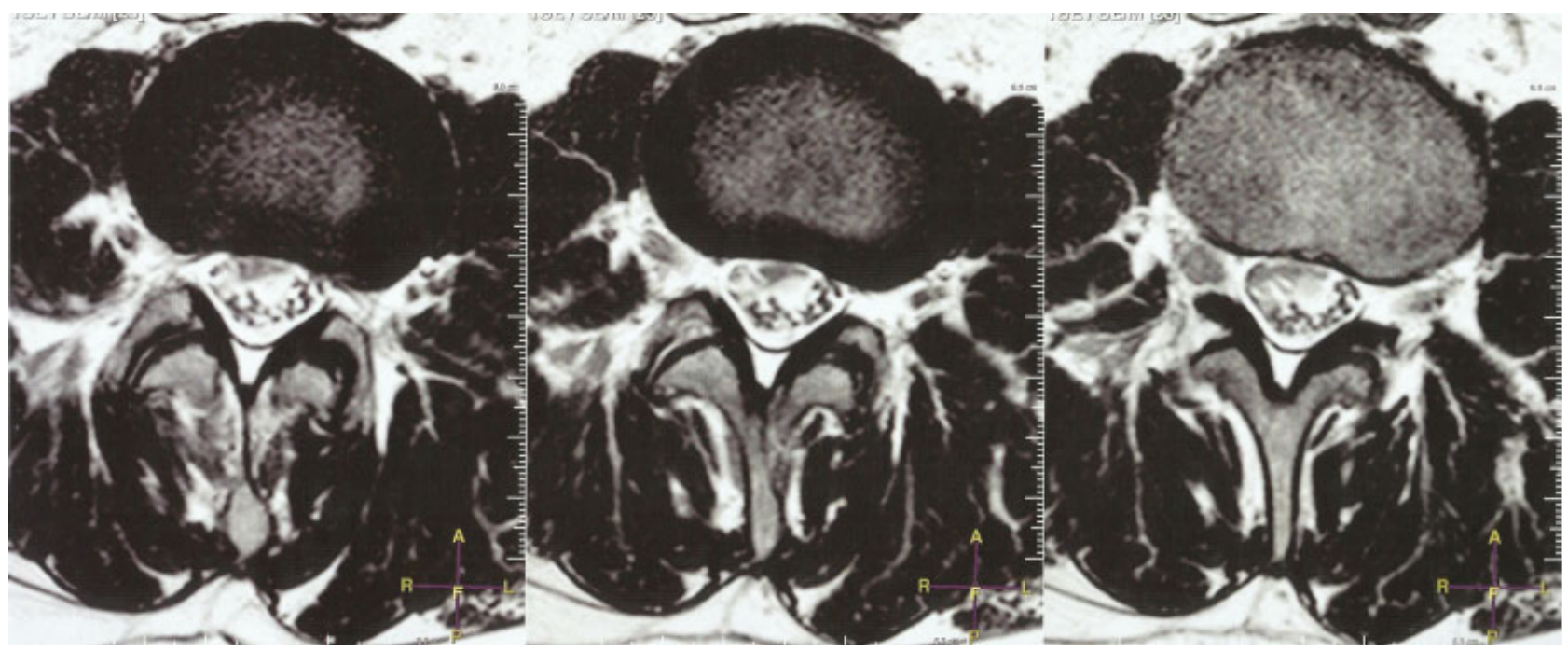

Fig. 3 Axial T2-weighted lumbosacral magnetic resonance imaging showing an intradural extramedullary expansive lesion glancing to the L3-L4 right foramen. 


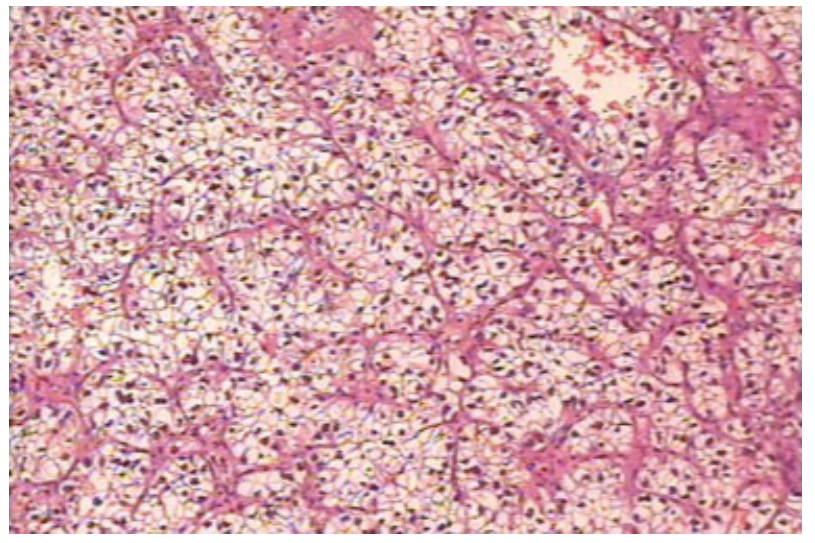

Fig. 4 Clear cell carcinoma. Neoplasic renal cells with highly lipidic and large cytoplasm encircled by small blood vessels. Hematoxylin and eosin stain, 100x magnification.

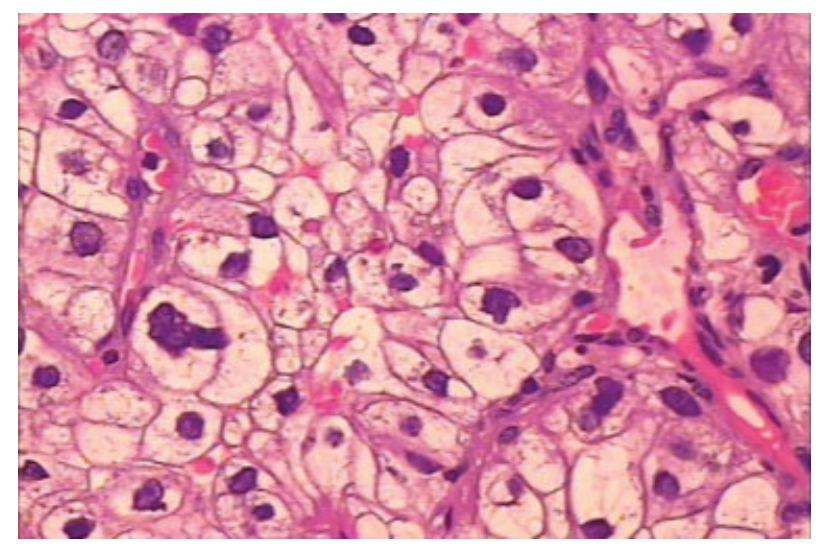

Fig. 5 Clear cell carcinoma. Neoplasic renal cells with highly lipidic cytoplasm, discreetly pleomorphic core. Hematoxylin and eosin stain, 400x magnification.

satisfactory strength recovery (muscle strength graded 3 on the legs and 4 on the thighs). Chemotherapy requirement was evaluated afterwards by the clinical oncology team.

\section{Discussion}

Metastatic dissemination to the intradural space includes: hematogenous, via the Batson plexus and the azygos vein, ${ }^{4}$ by lymphatic extension, and even by contiguous invasion. When considering primary brain tumors and even synchronous brain metastasis, cerebrospinal fluid (CSF) dissemination must also be considered. This last type of metastatic dissemination may be related to the action of gravity; therefore, many extradural intramedullary metastases concentrate at the nerve roots of the cauda equina. ${ }^{5,8}$ A study has proposed that perineural dissemination may also occur, spreading from the renal plexus through the sympathetic chain, and then to the intradural space, also affecting the cauda equina in some cases. $^{9}$

The clinical features of spinal metastasis are vast and include symptoms due to local periosteal lesions, to adjacent tissue invasion, and, lastly, due to the compression of the roots of the nerves. ${ }^{4}$ In general terms, the patients can present with pain, autonomic symptoms, motor and sensitive deficits. General signs may also be present, as in most consumptive systemic illnesses, such as weight loss, appetite loss, and sweating. ${ }^{2,3}$ The intensity of the symptoms range in magnitude according to the aggressiveness of the tumor, which is represented by its replication rate, extension, and histological type.

The pain may be mechanical, radicular or local, and is the most common initial symptom, affecting up to $90 \%$ of the patients. ${ }^{2,5}$ Several types of pain may be presented concurrently, since they have different mechanisms. Local pain is related to periosteal inflammation as a consequence of the tumoral growth; mechanical pain happens due to an osseous deformity that causes vertebral instability. As for the radicular type, it is related to the compression or irritation of the roots of the nerves. ${ }^{2,7}$ In spite of their distinct sensitive features, or even of their absence, all of the pain types should lead to investigation. ${ }^{2,7}$ Especially in patients with previous cancer diagnosis or even with just general risk factors to neoplasms, a precocious investigation leads to an early diagnosis and treatment. ${ }^{10}$

In the case reported in the present article, motor dysfunction was also present as part of the natural course observed in the typical clinical syndrome, originated by spinal metastasis. The progression of the syndrome may consist of cervicalgia and low back pain followed by sensory and motor impairment - with well delimited dermatomal distribution and autonomic disturbance (erectile, bladder, and bowel dysfunction). The loss of muscle strength is critical and will advance to paralysis, unless proper early treatment is provided, especially considering intramedullary metastasis, which progresses even faster. ${ }^{2}$ Autonomic disturbances are related to a worse prognosis and tend to appear only after 2 months after the onset of pain; this scenario highlights a delay in the diagnosis. ${ }^{2}$

Intradural extramedullary metastases tend to progress rapidly from pain to motor dysfunctions, and symptomatic patients are mostly classified in advanced stages of the disease. ${ }^{11}$ A more precise investigation and staging is done to guide the treatment options. When assuming a case is likely metastatic, it is essential to intensify the investigation with additional methods to confirm the hypothesis and plan interventions more precisely. Amongst a vast amount of imaging methods currently available, MRI is considered the gold standard to assess spinal metastasis. ${ }^{8}$ This method offers excellent results at a fair cost and is widely accessible, besides its superior sensitivity to evaluate soft tissues in detail, when compared with other imaging studies., ${ }^{2,7}$

The treatment for spinal metastasis is palliative, as its main goal is to relief discomfort and pain, improving the quality of life of the patient. ${ }^{4,5}$ The estimated survival time postdiagnosis is of between 4 and 7 months. ${ }^{11}$ The treatment options vary from radiotherapy to chemotherapy, surgical decompression, and even hormonal therapy. The therapeutic modality is chosen based on the performance status and clinical stability of the patient, and on if the life expectation is inferred to be $>3$ months. ${ }^{2,6,7}$ Some authors have suggested that, regarding the possible association between metastasis and primary CNS tumors, it may be appropriate to perform neuraxial chemotherapy and radiotherapy concomitantly. ${ }^{5}$ 
Surgical therapy is an acceptable choice that improves the quality of life, but has no effect in prolonging survival ${ }^{11}$

In our case, surgical therapy was the best option, considering the previous good performance status of the patient, the fast advancing muscle weakness, and also the availability of an experienced neurosurgery team in a well-equipped hospital. Surgery can also be considered as a valid treatment modality, showing benefits especially when intractable pain is part of the case, or to improve intense neurological symptoms, therefore improving the quality of life. ${ }^{11,12}$ In clinical cases involving the cauda equina or tumors without cleavage plan, we should not aim for total gross resection, since a decompressive laminectomy may offer a satisfactory result with lesser risks. ${ }^{13}$ A new possibility in surgical modality is stereotactic radiosurgery, which shall target the tumoral cells and preserve healthy tissues, benefiting patients with high surgical risk and also those who remain with residual disease postsurgery. ${ }^{13}$ Still, little research has been done to elucidate the outcomes in patients submitted to this treatment. ${ }^{13}$

\section{Conclusion}

Cases involving intradural extramedullary spinal metastases are not commonly seen in the clinical practice, particularly when the primary site of the tumor is the kidney. Metastases themselves are indicatives of advanced disease, but considering the spinal impairment, the treatment can be palliative only. Surgery aims to reduce pain symptoms and to improve the quality of life of the patient. Comparative studies regarding specific indications to the modality of the surgery, as well as technology advances in oncologic therapies, are necessary so that the treatment improves and we move forward toward better results for our patients.

Conflicts of Interest

The authors have no conflicts of interest to declare.

\section{References}

1 Joaquim AF, Ghizoni E, Tedeschi H, Pereira EB, Giacomini LA. Radiocirurgia estereotáxica para metástases de coluna vertebral: revisão de literatura. Einstein (Sao Paulo) 2013;11(02):247-255

2 Sciubba DM, Petteys RJ, Dekutoski MB, et al. Diagnosis and management of metastatic spine disease. A review. J Neurosurg Spine 2010;13(01):94-108

3 Prevedello DMS, Koerbel A, Tatsui CE, et al. Fatores prognósticos no tratamento dos tumores intradurais extramedulares: estudo de 44 casos. Arq Neuropsiquiatr 2003;61(2A):241-247

4 Araujo JLV, Veiga JCE, Figueiredo EG, Barboza VR, Daniel JW, Panagopoulos AT. Manejo das neoplasias metastáticas da coluna vertebral - uma atualização. Rev Col Bras Cir 2013;40(06):508-514

5 Perrin RG, Livingston KE, Aarabi B. Intradural extramedullary spinal metastasis. A report of 10 cases. J Neurosurg 1982;56(06): 835-837

6 Akhavan A, Mehrabaniyan MR, Jarahi M, Navabii H. Intradural extramedullary metastasis from papillary carcinoma of thyroid. BMJ Case Rep 2012;2012:x

7 Santos VG, Cavalcante RAC, Marques RAS, Zaccariotti VA. Metástase espinhal intradural e extramedular: relato de caso. Arq Bras Neurocir 2015;34(03):229-231

8 Frey I, Le Breton C, Lefkopoulos A, et al. Intradural extramedullary spinal canal secondary neoplasms: MR findings in 30 patients. Eur Radiol 1998;8(07):1187-1192

9 Capek S, Krauss WE, Amrami KK, Parisi JE, Spinner RJ. Perineural Spread of Renal Cell Carcinoma: A Case Illustration with a Proposed Anatomic Mechanism and a Review of the Literature. World Neurosurg 2016;89:728.e11-728.e17

10 Kim D-Y, Lee J-K, Moon S-J, Kim S-C, Kim C-S. Intradural spinal metastasis to the cauda equina in renal cell carcinoma: a case report and review of the literature. Spine 2009;34(24):E892-E895

11 Wu J, Zheng W, Xiao J-R, Sun X, Liu W-Z, Guo Q. Health-related quality of life in patients with spinal metastases treated with or without spinal surgery: a prospective, longitudinal study. Cancer 2010;116(16):3875-3882

12 Wolf A, Johnstone R, Siddiqi F. Intradural Extramedullary Spinal Cord Metastasis of the Prostate: A Case Presentation and Review of the Literature. Can J Neurol Sci 2016;43(04):588-592

13 Purvis TE, Goodwin CR, Lubelski D, Laufer I, Sciubba DM. Review of stereotactic radiosurgery for intradural spine tumors. CNS Oncol 2017;6(02):131-138 